\title{
Antimicrobial Effect of $2 \%$ Sodium Hypochlorite and $2 \%$ Chlorhexidine Tested by Different Methods
}

\author{
Carlos ESTRELA ${ }^{1}$ \\ Rosane Galhardo RIBEIRO ${ }^{2}$ \\ Cyntia R.A. ESTRELA ${ }^{1}$ \\ Jesus Djalma PÉCORA ${ }^{3}$ \\ Manoel Damião SOUSA-NETO2 \\ ${ }^{1}$ Faculty of Dentistry, Federal University of Goiás, Goiânia, GO, Brazil \\ ${ }^{2}$ Faculty of Dentistry, University of Ribeirão Preto (UNAERP), Ribeirão Preto, SP, Brazil \\ ${ }^{3}$ Faculty of Dentistry of Ribeirão Preto, University of São Paulo (USP), Ribeirão Preto, SP, Brazil
}

\begin{abstract}
The objective of this study was to analyze the antimicrobial effect of $2 \%$ sodium hypochlorite (NaOCl) and $2 \%$ chlorhexidine (CHX) by agar diffusion test and by direct exposure test. Five microorganisms: Staphylococcus aureus, Enterococcus faecalis, Pseudomonas aeruginosa, Bacillus subtilis, Candida albicans, and one mixture of these were used. These strains were inoculated in brain heart infusion (BHI) and incubated at $37^{\circ} \mathrm{C}$ for $24 \mathrm{~h}$. For the agar diffusion test (ADT), 18 Petri plates with $20 \mathrm{ml}$ of BHI agar were inoculated with $0.1 \mathrm{ml}$ of the microbial suspensions, using sterile swabs that were spread on the medium, obtaining growth in junction. Fifty-four paper disks $(9 \mathrm{~mm}$ in diameter) were immersed in the experimental solutions for $1 \mathrm{~min}$. Subsequently, three papers disks containing one of the substances were placed on the BHI agar surface in each agar plate. The plates were maintained for $1 \mathrm{~h}$ at room temperature, and then incubated at $37^{\circ} \mathrm{C}$ for $48 \mathrm{~h}$. The diameter of microbial inhibition was measured around the papers disks containing the substances. For the direct exposure test, $162 \# 50$ sterile absorbent paper points were immersed in the experimental suspensions for $5 \mathrm{~min}$, and were then placed on Petri plates and covered with one of the irrigant solutions, or with sterile distilled water (control group). After intervals of 5,10 and $30 \mathrm{~min}$, the paper points were removed from contact with the solutions and individually immersed in $7 \mathrm{ml}$ of Letheen Broth, followed by incubation at $37^{\circ} \mathrm{C}$ for $48 \mathrm{~h}$. Microbial growth was evaluated by turbidity of the culture medium. A $0.1 \mathrm{ml}$ inoculum obtained from the Letheen Broth was transferred to $7 \mathrm{ml}$ of BHI, and incubated at $37^{\circ} \mathrm{C}$ for $48 \mathrm{~h}$. Bacterial growth was again evaluated by turbidity of the culture medium. Gram stain of BHI cultures was used for verification of contamination and growth was determined by macroscopic and microscopic examination. The best performance of antimicrobial effectiveness of $\mathrm{NaOCl}$ was observed in the direct exposure test, and of CHX was observed in the agar diffusion test. The magnitude of antimicrobial effect was influenced by the experimental methods, biological indicators and exposure time.
\end{abstract}

Key Words: sodium hypochlorite, chlorhexidine, irrigant solutions, intracanal dressing.

\section{INTRODUCTION}

The success of endodontic treatment is directly influenced by elimination of microorganisms in infected root canals. With apical periodontitis, effective antimicrobial agents are necessary. The irrigant solutions are very important during root canal preparation because they aid in the cleaning of the root canal, lubricate the files, flush out debris, and have an antimicrobial effect and tissue dissolution, without damage to periapical tissues. The selection of an ideal irrigant depends on its action on microorganisms and periapical tissues.
Sodium hypochlorite and chlorhexidine are antimicrobial agents frequently used in the treatment of endodontic and periodontal infections (1-5).

Estrela et al. (2) discussed the mechanism of action of sodium hypochlorite based on its antimicrobial and physico-chemical properties. The antimicrobial effectiveness of sodium hypochlorite based on its high $\mathrm{pH}$ (hydroxyl ions action) seems similar to the mechanism of action of calcium hydroxide (6). The high $\mathrm{pH}$ of sodium hypochlorite interferes in cytoplasmic membrane integrity with irreversible enzymatic inhibition, biosynthetic alterations in cell metabolism and phospholipid destruction observed in lipidic 
peroxidation. The amino acid chloramination reaction forming chloramines interferes in cell metabolism. Oxidation promotes irreversible enzymatic inhibition of bacteria replacing hydrogen with chlorine. Enzyme inactivation can be observed in the reaction of chlorine with amino groups $\left(\mathrm{NH}_{2}^{-}\right)$and an irreversible oxidation of sulphydryl groups ( $\mathrm{SH}$ ) of bacteria enzymes (cystein). Thus, sodium hypochlorite presents antimicrobial activity with action on bacterial essential enzymatic sites promoting irreversible inactivation originated by hydroxyl ions and chloramination action. Dissolution of organic tissue can be verified in the saponification reaction when sodium hypochlorite destroys fatty acids and lipids resulting in soap and glycerol.

Chlorhexidine is a cationic agent (biguanide group; 4-chlorophenyl radical), which exhibits antibacterial activity. The cationic nature of the compound promotes connection with anionic compound at the bacterial surface (phosphate groups from teicoic acid at Gram-positive and lipopolysaccharide at Gram-negative bacteria) capable of altering its integrity. The potassium ion, being a small entity, is the first substance to appear when the cytoplasmic membrane is damaged. The alteration of the cytoplasmic membrane permeability promotes precipitation of cytoplasmic proteins, alters cellular osmotic balance, interferes with metabolism, growth, cell division, inhibits the membrane ATPase and inhibits the anaerobic process (3,4,7-9).

Although $\mathrm{NaOCl}$ and $\mathrm{CHX}$ present antibacterial activity, both substances have distinct characteristics. Various research results have shown disagreement when comparing the antimicrobial effect of these solutions (10-17). Different experimental methods, biological indicators, concentrations, or the period of analysis may have caused these differences.

Considering these facts, the purpose of this study was to evaluate the antimicrobial effect of sodium hypochlorite and chlorhexidine (at $2 \%$ ) on microorganisms with different structural characteristics (facultative aerobic Gram-positive coccus; facultative aerobic Gram-negative rods; aerobic Gram-positive rods, sporeforming and one yeast) by two methods (agar diffusion test and direct exposure test).

\section{MATERIAL AND METHODS}

Five standard microorganism strains obtained from the American Type Culture Collection were used for this study: Staphylococcus aureus (ATCC 6538), Enterococcus faecalis (ATCC 29212), Pseudomonas aeruginosa (ATCC 27853), Bacillus subtilis (ATCC 6633) and one yeast, Candida albicans (ATCC 10231). One mixture of these was also included in the study.

The strains were inoculated in $7 \mathrm{ml}$ brain heart infusion (BHI; Difco Laboratories, Detroit, MI, USA) and incubated at $37^{\circ} \mathrm{C}$ for $24 \mathrm{~h}$. The 5 biological indicators were cultivated on the surface of brain heart infusion agar (BHIA; Difco Laboratories) following the same incubation conditions. Microbial cells were resuspended in saline to give a final concentration of about $3 \times 10^{8}$ cells $/ \mathrm{ml}$, similar to that of tube \#1 of the MacFarland scale. One $\mathrm{ml}$ of each of these pure suspensions was used to obtain a mixture of the test microorganisms.

The irrigant solutions tested in this experiment were $2 \%$ sodium hypochlorite (Soda Clorada, Biodinâmica, Ibiporá, PR, Brasil), 2\% chlorhexidine digluconate (F.G.M., Joinville, SC, Brazil), and sterile distilled water.

For the agar diffusion test, 18 Petri plates with 20 $\mathrm{ml}$ of BHIA were inoculated with $0.1 \mathrm{ml}$ of the microbial suspensions, using sterile swabs that were spread on the medium, obtaining growth in junction. Fifty-four paper disks ( $9 \mathrm{~mm}$ in diameter) were immersed in the experimental solutions for $1 \mathrm{~min}$ and then 3 paper disks were placed over the BHIA surface in each agar plate. The plates were maintained for $1 \mathrm{~h}$ at room temperature, and then incubated at $37^{\circ} \mathrm{C}$ for $48 \mathrm{~h}$. The diameter of microbial inhibition was measured around the paper disks containing the substances. Positive and negative controls were done, maintaining the plates inoculated and without inoculum, for the same time periods and under identical incubation conditions. All assays were carried out under aseptic conditions.

For the direct exposure test, one hundred and sixty-two \#50 sterile absorbent paper points (Tanari, Tanariman Indústria, Ltda., Manacaru, AM, Brazil) were immersed in the experimental suspensions for 5 min and were then placed on Petri plates and covered with one of the 2 irrigant solutions, or with sterile distilled water (control group). At intervals of 5, 10 and $30 \mathrm{~min}, 54$ absorbent paper points were removed from contact with the substances, individually transported, and immersed in $7 \mathrm{ml}$ of Letheen Broth (LB, Difco Laboratories), a medium containing neutralizers or added with neutralizers lecithin, Tween 80 and sodium thiosul- 
fate (P.A., Art Laboratories, Campinas, SP, Brazil) in appropriate concentrations, and subsequently incubated at $37^{\circ} \mathrm{C}$ for $48 \mathrm{~h}$. Microbial growth was analyzed by turbidity of the culture medium. Subsequently, a 0.1-ml inoculum obtained from Letheen Broth was transferred to $7 \mathrm{ml}$ of $\mathrm{BHI}$, under identical incubation conditions.
Microbial growth was also evaluated by turbidity of the culture medium. Gram stain of BHI cultures was used for verification of contamination and growth was determined with macroscopic and microscopic (Gram stain) examination. All assays were carried out in triplicate under aseptic conditions.
Table 1. Means of the diameters (in $\mathrm{mm}$ ) of the inhibition zones by the agar diffusion test.

\begin{tabular}{lcccccc}
\hline & $\begin{array}{c}\text { S. aureus } \\
\text { AGPC }\end{array}$ & $\begin{array}{c}\text { E. faecalis } \\
\text { AGPC }\end{array}$ & $\begin{array}{c}\text { P.aeruginosa } \\
\text { AGNR }\end{array}$ & $\begin{array}{c}\text { B. subtillis } \\
\text { AGPR* }\end{array}$ & $\begin{array}{c}\text { C. albicans } \\
\text { Yeast }\end{array}$ & Mixture \\
\hline $2 \% \mathrm{NaOCl}$ & 14 & 12 & 12 & 0 & 12 & 0 \\
$2 \% \mathrm{CHX}$ & 18 & 18 & 24 & 18 & 16 & 18 \\
Distilled water & 0 & 0 & 0 & 0 & 0 & 0 \\
\hline
\end{tabular}

$2 \% \mathrm{NaOCl}: 2 \%$ sodium hypochlorite; $2 \% \mathrm{CHX}: 2 \%$ chlorhexidine. AGPC: aerobic Grampositive coccus; AGNR: aerobic Gram-negative rods; AGPR*: aerobic Gram-positive rods, spore-forming.

Table 2. Antimicrobial effect of irrigant solutions by the direct exposure test.

\begin{tabular}{|c|c|c|c|}
\hline & $5 \mathrm{~min}$ & $10 \mathrm{~min}$ & $30 \mathrm{~min}$ \\
\hline \multicolumn{4}{|l|}{$2 \% \mathrm{NaOCl}$} \\
\hline S. aureus (AGPC) & - & -- & --- \\
\hline E. faecalis (AGPC) & -- & -- & -- \\
\hline P. aeruginosa (AGNR) & -- & -- & -- \\
\hline B. subtillis (AGPR) & -- & -- & -- \\
\hline C. albicans (Yeast) & -- & -- & --- \\
\hline Mixture & -- & --- & --- \\
\hline \multicolumn{4}{|l|}{$2 \% \mathrm{CHX}$} \\
\hline S. aureus (AGPC) & -- & -- & --- \\
\hline E. faecalis (AGPC) & -- & -- & --- \\
\hline P. aeruginosa (AGNR) & ++ & ++ & +++ \\
\hline B. subtillis (AGPR) & ++ & ++ & +++ \\
\hline C. albicans (Yeast) & -- & -- & --- \\
\hline Mixture & +++ & +++ & +++ \\
\hline \multicolumn{4}{|l|}{ Distilled water } \\
\hline S. aureus (AGPC) & +++ & +++ & +++ \\
\hline E. faecalis (AGPC) & +++ & +++ & +++ \\
\hline P. aeruginosa (AGNR) & +++ & +++ & +++ \\
\hline B. subtillis (AGPR) & +++ & +++ & +++ \\
\hline C. albicans (Yeast) & +++ & +++ & +++ \\
\hline Mixture & +++ & +++ & +++ \\
\hline
\end{tabular}

+++ , presence of growth; - - -, absence of growth.

$2 \% \mathrm{NaOCl}: 2 \%$ sodium hypochlorite; $2 \% \mathrm{CHX}: 2 \%$ chlorhexidine. AGPC: aerobic Grampositive coccus; AGNR: aerobic Gram-negative rods; AGPR*: aerobic Gram-positive rods, spore-forming.

\section{RESULTS}

The results of the agar diffusion test are shown in Table 1 and of the direct exposure test in Table 2. The data showed that $2 \%$ sodium hypochlorite and $2 \%$ chlorhexidine digluconate have antimicrobial effects against the biological indicators tested. The magnitude of antimicrobial effect was influenced by the experimental methods, biological indicators and exposure time. The best performance of antimicrobial effectiveness of $\mathrm{NaOCl}$ was observed in the direct exposure test, and of CHX was observed in the agar diffusion test.

\section{DISCUSSION}

All in vitro experimental methods have advantages and disadvantages. In the agar diffusion test, the size of the microbial inhibition zone depends upon the solubility and diffusibility of the test substance and, therefore, may not express its full effective potential. The direct exposure test is correlated to substance effectiveness and its direct contact with the microorganism; it seems to be independent of the other variables and appears to be a practical laboratory test (20). Facultative bacteria were used in the present study because they have been identified in teeth with failure of endodontic treatment.

The interpretation of re- 
search results must be careful. Careless analyzes may be responsible for classic errors. It is very important to treat extrapolations of in vitro to in vivo studies with care. Others properties beyond antimicrobial activity must also be investigated before the final choice of an irrigant solution for clinical use, such as minimum inhibitory concentration, tissue dissolution capacity, detoxification of endotoxin (lipid A) and acceptable biologic compatibility.

Vahdaty et al. (5) analyzed the efficacy of $2 \%$ $\mathrm{CHX}$ and $2 \% \mathrm{NaOCl}$ on dentinal tubules infected with E. faecalis. Dentine was removed from the canal wall with sterile burs of increasing diameter to give samples of 100, 100-300 and 300-500 $\mu \mathrm{m}$ deep. The results indicated that $\mathrm{CHX}$ and $\mathrm{NaOCl}$ were equally effective antibacterial agents at similar concentrations against the test microorganism. They significantly reduced the bacterial counts in the first $100 \mu \mathrm{m}$ of dentinal tubules, however up to $50 \%$ of dentine samples remained infected following use of both agents. Jeansonne and White (9) compared 2\% $\mathrm{CHX}$ and $5.25 \% \mathrm{NaOCl}$ as antimicrobial endodontic irrigants in freshly extracted human teeth with pulp pathosis. The results showed that the number of post-irrigant positive cultures and the number of colony-forming units in positive cultures obtained from CHX-treated teeth were lower than the numbers obtained from $\mathrm{NaOCl}$-treated teeth, but the differences were not statistically significant. Heling and Chandler (10) investigated the antimicrobial effect of irrigant combinations within dentinal tubules and concluded that $0.12 \% \mathrm{CHX}$ and $1 \% \mathrm{NaOCl}$ were similarly effective. Silva (16) verified in vivo the antimicrobial action of $1 \% \mathrm{NaOCl}$ and $2 \% \mathrm{CHX}$ as endodontic irrigants. Using $1 \% \mathrm{NaOCl}$ as irrigant, 16.7 and $83.3 \%$ of the canals appeared to be positive in the microbiological test, immediately and after 7 days of therapy; with $2 \% \mathrm{CHX}$, the percentages of positive cultures were 8.3 and $41.7 \%$, taking into account the immediate and residual effects, indicating that both irrigants possess the same effect immediately after biochemical treatment. However, irrigation with $2 \% \mathrm{CHX}$ has shown more efficient than $1 \% \mathrm{NaOCl}$ when 7-day residual effectiveness is considered.

Estrela (17) determined the minimum inhibitory concentration of $1 \% \mathrm{NaOCl}$ and $2 \% \mathrm{CHX}$ for inhibiting $S$. aureus, E. faecalis, $P$. aeruginosa, B. subtilis, $C$. albicans and a mixture of these microorganisms, with a serial dilution of 10 . The results showed that the mini- mum concentration of $1 \% \mathrm{NaOCl}$ required for inhibiting S. aureus, E. faecalis, $P$. aeruginosa and C. albicans was $0.1 \%$, and $1 \%$ for B. subtilis and the mixture. $2 \%$ CHX showed minimum inhibitory concentration of $0.000002 \%$ for $S$. aureus, $0.002 \%$ for $P$. aeruginosa, and $0.02 \%$ for E. faecalis, B. subtilis, C. albicans and the mixture.

$\mathrm{NaOCl}$ has an excellent capability of tissue dissolution. Spanó et al. (18) studied in vitro the solvent effect of four concentrations of $\mathrm{NaOCl}$ solutions $(0.1 \%$, $1.0 \%, 2.5 \%$ and $5.0 \%$ ) on bovine pulp tissue, the level of residual chlorine $\mathrm{pH}$ and surface tension before and after tissue dissolution. The results showed that all concentrations of $\mathrm{NaOCl}$ reduced the $\mathrm{pH}$ and the surface tension, and the higher concentrations of the solutions had the least consumption of chlorine during tissue dissolution. The residual chlorine was directly proportional to the concentration in the process of pulp tissue dissolution and there was residual chlorine at all concentrations used in this study.

Buck et al. (19) evaluated the detoxification of endotoxin by endodontic irrigants $(\mathrm{CHX}, \mathrm{NaOCl}$, chlorhexidine chloride, ethanol, EDTA, water) and $\mathrm{Ca}(\mathrm{OH})_{2}$. The results showed that the biologically active portion of endotoxin, lipid A, is hydrolyzed by highly alkaline chemicals, namely $\mathrm{Ca}(\mathrm{OH})_{2}$ or the mixture of $\mathrm{CHX}, \mathrm{NaOCl}$ and ethanol. EDTA, $\mathrm{NaOCl}$, CHX, chlorhexidine chloride, ethanol and water (control) showed little or no detoxifying ability for lipid A.

The use and indication of $\mathrm{NaOCl}$ by the majority of dentists occur because this irrigant presents important properties, such as antimicrobial effect, tissue dissolution capacity and acceptable biologic compatibility in less concentrated solutions $(0.5-1 \%)$. Although CHX showed antibacterial effects, the ability of tissue dissolution is still unknown. CHX may be indicated when a patient is allergic to $\mathrm{NaOCl}$ or to combat specific bacteria susceptible to this substance. Further studies are required to determine the antimicrobial effectiveness of irrigant solutions in infected root canals with apical periodontitis.

We conclude that $2 \% \mathrm{NaOCl}$ and $2 \% \mathrm{CHX}$ have antimicrobial effects against the biological indicators tested (Staphylococcus aureus, Enterococcus faecalis, Pseudomonas aeruginosa, Bacillus subtilis, Candida albicans and a mixture). The magnitude of this effect was influenced by the experimental method, characteristics of the microorganisms and the exposure time. 


\section{RESUMO}

O objetivo deste estudo foi testar o efeito antimicrobiano do hipoclorito de sódio a $2 \%$ e da clorexidina a $2 \%$ por meio de dois métodos: difusão em agar e exposição direta. Cinco microrganismos: Staphylococcus aureus, Enterococcus faecalis, Pseudomonas aeruginosa, Bacillus subtilis, Candida albicans, e uma mistura foram utilizados. As cepas foram inoculadas em BHI e incubadas a $37^{\circ} \mathrm{C}$ por $24 \mathrm{~h}$. Para o teste de difusão em agar, 18 placas de Petri com $20 \mathrm{ml}$ de BHIA foram inoculadas com 0,1 $\mathrm{ml}$ das suspensões microbianas, com auxílio de swab esterilizado, de modo a se obter um crescimento confluente. 54 discos de papel com $9 \mathrm{~mm}$ de diâmetro foram imersos nas soluções experimentais durante $1 \mathrm{~min}$. A seguir, em cada placa, 3 discos de papel contendo uma das soluções irrigantes foram colocadas sobre a superfície do BHIA. As placas foram mantidas por $1 \mathrm{~h}$ em temperatura ambiente, e incubadas a $37^{\circ} \mathrm{C}$ por $48 \mathrm{~h}$. Os diâmetros dos halos de inibição microbiana foram medidos sobre os discos de papel contendo as substâncias, valendo-se de duas medidas de forma perpendicular entre si, sendo obtido a média de seus tamanhos. Para o teste de exposição direta, 162 pontas de pape absorvente esterilizadas no 50 foram imersas na suspensão experimental por $5 \mathrm{~min}$, e foram colocadas sobre uma placa de Petri e cobertas com $10 \mathrm{ml}$ de uma das soluções irrigantes, ou com a água destilada. Em intervalos de 5, 10 e $30 \mathrm{~min}$, as pontas de papel foram removidas do contato com as soluções teste e individualmente transportadas e imersas $7 \mathrm{ml}$ de Letheen Broth, e incubadas a $37^{\circ} \mathrm{C}$ for $48 \mathrm{~h}$. $\mathrm{O}$ crescimento microbiano foi avaliado pela turbidade do meio de cultura. Um inóculo de $0.1 \mathrm{ml}$ obtido do Letheen Broth foi transferido para $7 \mathrm{ml}$ of BHI, e incubado nas mesmas condições descritas. $\mathrm{O}$ crescimento microbiano foi novamente avaliado pela turbidade do meio de cultura. Os resultados mostraram efetividade antimicrobiana para as duas soluções irrigadoras testadas. A magnitude do efeito antimicrobiano foi influenciada pelo método experimental, pelos microrganismos e pelo tempo de exposição.

\section{REFERENCES}

1. Byström A, Sundqvist G. Bacteriologic evaluation of the effects of $0.5 \%$ sodium hypochlorite in endodontic therapy. Oral Surg 1981;89:321-328.

2. Estrela C, Estrela CRA, Barbin EL, Spanó JC, Marchesan MA, Pécora JD. Mechanism of action of sodium hypochlorite. Braz Dent J 2002;2:113-117.

3. Rolla G, Melsen B. On the mechanism of the plaque inhibition by chlorhexidine. J Dent Res 1975;54:57-62.

4. Jenkins S, Addy M, Wade W. The mechanism of action of chlorhexidine. J Clin Periodontol 1988; 15:415-424.
5. Vahdaty A, Pitt Ford TR, Wilson RF. Efficacy of chlorhexidine in disinfecting dentinal tubules in vitro. Endod Dental Traumatol 1993;9:243-248.

6. Estrela C, Sydney GB, Bammann LL, Felippe Jr O. Mechanism of action of calcium and hydroxyl ions of calcium hydroxide on tissue and bacteria. Braz Dent J 1995:6:85-90.

7. Hugo WB, Russel AD. Pharmaceutical Microbiology. 5th ed. Oxford: Blackwell; 1992. p 245-299.

8. Denton GW. Chlorhexidine. In: Disinfection, sterilization and preservation. Block SS. ed. 4th ed. Philadelphia: Lea \& Febiger; 1991. p 274-289.

9. Jeansonne MJ, White RR. A comparison of $2 \%$ chlorhexidine gluconate and $5.25 \%$ sodium hypochlorite as antimicrobial endodontic irrigant. J Endodon 1994;20:276-278.

10. Heling I, Chandler NP. Antimicrobial effect of irrigant combinations within dentinal tubules. Int Endod J 1998;31:8-14.

11. Gomes BPFA, Ferraz CCR, Vianna ME, Berber VB, Teixeira FB, Souza-Filho FJ. In vitro antimicrobial activity of several concentrations of sodium hypochlorite and chlorhexidine gluconate in the elimination of Enterococcus faecalis. Int Endod J 2001;34: 424-428.

12. Ringel AM, Patterson SS, Newton CW, Miller CH, Mulhern JM. In vivo evaluation of chlorhexidine gluconate solution and sodium hypochlorite solution as root canal irrigants. J Endodon 1992;8:200-204.

13. Siqueira JF, Batista MD, Fraga RC, Uzeda M. Antimicrobial effects of endodontic irrigants on black-pigmented Gram-negative anaerobes and facultative bacteria. J Endodon 1998;24:414416.

14. Ayhan H, Sultan N, Cirak M, Ruhi MZ, Bodur H. Antimicrobial effects of various endodontic irrigants on selected microorganisms. Int Endod J 1999;32:99-102.

15. Komorowski R, Grad H, Wu XY, Friedman S. Antibacterial substantivity of chlorhexidine-treated bovine root dentin. J Endodon 2000;26:315-317.

16. Silva CAG. Efetividade antimicrobiana do hipoclorito de sódio e clorexidina como irrigantes endodônticos. [Master's thesis]. Porto Alegre: Luteran University of Brasil, 1999.

17. Estrela CRA. Eficácia antimicrobiana de soluções irrigadoras de canais radiculares. [Master's thesis]. Goiânia: Federal University of Goiás; 2000. 80 p. Internet site: http://estrela.neomundi.com.br/

18. Spanó JCE, Barbin EL, Santos TC, Guimarães LF, Pécora JD. Solvent action of sodium hypochlorite on bovine pulp and physico-chemical properties of resulting liquid. Braz Dent $\mathbf{J}$ 2001;12:154-157.

19. Buck RA, Cai J, Eleaser PD, Staat RH, Hurst HE. Detoxification of endotoxin by endodontic irrigants and calcium hydroxide. J Endodon 2001;27:325-327.

20. Estrela C, Estrela CRA, Bammann LL, Pécora JD. Two methods to evaluate the antimicrobial action of calcium hydroxide paste. J Endodon 2001;27:5-7. 